\title{
Sewage sludge as a source of triclosan-resistant bacteria
}

\author{
Kristína Lépesováa, Monika Krahulcováa, \\ Tomáš Mackul’ak ${ }^{\mathrm{b}}$, Lucia Bírošováa \\ ${ }^{a}$ Institute of Food Science and Nutrition, \\ Faculty of Chemical and Food Technology, STU in Bratislava, \\ Radlinského 9, 81237 Bratislava, Slovak Republic \\ ${ }^{b}$ Institute of Chemical and Environmental Engineering, \\ Faculty of Chemical and Food Technology, STU in Bratislava, \\ Radlinského 9, 81237 Bratislava, Slovak Republic \\ kristina.lepesova@stuba.sk
}

\begin{abstract}
Subinhibitory concentrations of antibiotics and biocides in wastewaters and sewage sludge have a great impact on the development of antibiotic resistance and its spread among bacteria. The aim of this work was to determine the occurrence of coliform bacteria and enterococci resistant to biocide triclosan in samples of sewage sludge. Subsequently, isolated strains of coliform bacteria were identified and characterized in terms of their antibiotic susceptibility and ability to form a biofilm. Occurrence of the studied bacteria was monitored in three samples of stabilized sludge from three different wastewater treatment plants (Vrakuña, Petržalka, and Senec). The number of triclosan-resistant coliforms was the highest in the sludge sample from the wastewater treatment plant in Senec and the lowest in the sludge sample from the wastewater treatment plant in Petržalka. Triclosan-resistant Enterococcus spp. were not found in any sample of stabilized sludge. Most isolates were identified as Citrobacter freundii and Serratia spp. Triclosan-resistant isolates showed also resistance to antibiotics and the majority of them were strong biofilm producers.
\end{abstract}

Keywords: antibiotic resistance, biofilm, coliform bacteria, stabilized sludge, triclosan, wastewater treatment plant

Abbreviations: AMP - ampicillin, ATB - antibiotics, CFU - colony forming units, CIP - ciprofloxacin, CLSI - Clinical Laboratory Standards Institute, CMP - chloramphenicol, EQ - equivalent inhabitants, EU - European Union, EUCAST - European Committee on Antimicrobial Susceptibility Testing, GEN - gentamicin, MALDI-TOF - Matrix-Assisted Laser Desorption/Ionization-Time of Flight, MDR - multidrug-resistance, MIC - minimal inhibitory concentration, QAC - quaternary ammonium compounds, TET - tetracycline, WWTP - wastewater treatment plant

\section{Introduction}

Nowadays, the use of synthetic antimicrobial agents for disinfection and hygiene purposes is widespread not only in hospitals but also in industry and households (Carey and McNamara, 2015). Antiseptics, disinfectants and preservatives are biocidal products intended to destroy or control harmful or unwanted microorganisms (Kalkanci et al., 2015). In hospital settings, they found their application externally to disinfect the skin surface for infection prevention of microbial origin or in pre-operative procedures, as well as to disinfect other surfaces and tools (Nuñez and Moretton, 2007). In addition, biocides are widely used in the food industry particularly for disinfecting containers and equipments (Kalkanci et al., 2015). In households, they are sold for the decontamination of food preparation surfaces (e.g. Dettol), those perceived as microbiologically contaminated (e.g. toilets) and for general improvement of household cleanliness (Fraise, 2002). Recently, the use of antibacterial soaps is also widespread. These products of daily hygiene often contain triclosan or quaternary ammonium compounds (QACs). However, it has been found that soaps containing triclosan at commonly used concentrations $(0.1-0.45 \% \mathrm{w} / \mathrm{v})$ are no more effective in preventing infection symptoms and reducing the amount of bacteria on hands than regular soaps (Aiello, 2007).

Inappropriate and excessive use of biocides in various areas may lead to increased tolerance to biocides including triclosan, QACs, chlorhexidine and sodium phosphate. Since biocides enter the environment at low concentrations, the risk of resistant microorganism selection increases and cross-resistance to antibiotics (ATBs) can also occur (Kalkanci et al., 2015; Lavilla Lerma et al., 2015). Another problem compared to ATBs is that biocides are non-prescriptive and can occur at higher concentrations in wastewaters as ATBs. Therefore, resistance to biocides is currently attracting great interest (Kalkanci et al., 2015). 
The most important biocide triclosan (5-Chloro2-(2,4-dichlorophenoxy)phenol) (Fig. 1) is a synthetic chlorinated phenyl ether bisphenol with broad-spectrum antimicrobial properties (Middleton and Salierno, 2013).

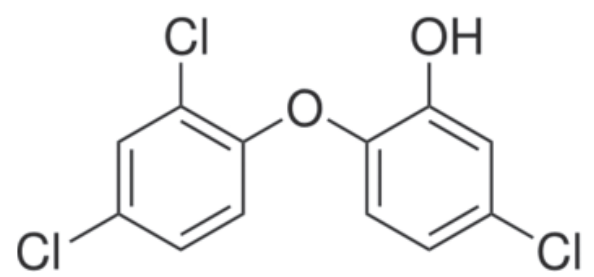

Fig. 1. Chemical structure of triclosan.

It is used as a component of many products such as soaps, toothpastes, shower gels, body lotions and deodorants (Kim et al., 2011; Carey and McNamara, 2015). According to the European Union Directive for cosmetics 76/768/EEC in products of daily use (including cosmetic products), the maximum permitted concentration of triclosan is $0.3 \%$ (Pintado-Herrera et al., 2014). Recently, the use of triclosan has been associated with many health and environmental impacts such as skin irritation, allergies or ecotoxicity of aquatic and terrestrial environment (for Japanese medaka fishes) (Chen et al., 2011). Triclosan can react with free chlorine in water and form chloroform which is classified as a carcinogen. Other compounds formed after their interaction are 2,4-dichlorophenols. Most of these molecules are subsequently after UV exposure converted to dioxins, which are thought to be endocrine disruptors (Rule et al., 2005). According to European Food Safety Authority in up to 450 tons of triclosan for commercial use were produced in the European Union (EU) in 2006, while in the USA its production ranged from 500 to 5000 tons in 1998 (EC, 2010; Carey and McNamara, 2015).

In general, biocide compounds act on multiple target sites in the microbial cell resulting in cell damage and bactericidal effect. However, triclosan in subinhibitory concentrations specifically targets the biosynthesis of fatty acids by the inhibition of NADH-dependent enoyl-ACP reductase fabI in Escherichia coli (EC, 2010; Sheridan et al., 2012). Recent studies also suggest that triclosan has a weak androgenic and anti-estrogenic effect making it a potential endocrine disruptor (Gatidou et al., 2007). Due to the wide and long-term use of triclosan, it can be found almost everywhere in the environment including wastewaters, soil, surface and drinking water, wastewater treatment plants (WWTPs), sediments as well as breast milk, blood and urine (Lee and Chu, 2013; Carey and McNamara, 2015). It has been shown that up to $79 \%$ of the original amount of triclosan flowing into a WWTP is removed by biodegradation and $15 \%$ is absorbed by activated sludge (Singer et al., 2002). Despite the high rate of degradation in WWTPs, its concentration in purified water is still relatively high (11-98 ng/L) due to high inlet concentrations (42-213 ng/L) (Baková, 2016). It is alarming that the minimal inhibitory concentration (MIC) values of triclosan for different microorganisms are significantly exceeded in the environment, especially in case of sediments, biomass or activated sludge (EC, 2010). The occurrence of triclosan was detected in agricultural soils as a result of fertilization with biomass originating from WWTPs (Kim et al., 2011). On the other hand, triclosan may also break down into methyl-triclosan, which is more stable and has higher potential for bioaccumulation (Rule et al., 2005).

The aim of the present work was to determine the occurrence of triclosan-resistant coliform bacteria and enterococci in samples of stabilized sludge. Subsequently isolated triclosan-resistant coliforms were identified and characterized in terms of their ATB susceptibility and the ability to form a biofilm.

\section{Materials and Methods}

\section{Characterization of collection points}

Samples of stabilized sludge were taken from the WWTPs in Petržalka, Vrakuňa and Senec. Those in Vrakuňa and Petržalka belong to the largest WWTPs in Slovakia. The Central WWTP in Vrakuňa as well as the WWTP in Petržalka include a mechanical and a biological treatment system and their own sludge and gas economy. While the capacity of the WWTP in Vrakuña is 300000 equivalent inhabitants (EQs), WWTP in Petržalka serves for 120000 EQs. Technical characteristics of these WWTPs were described previously (Mackulak et al., 2015a, 2015b). The sewage treatment system is the same for both WWTPs. Sludge is stabilized anaerobically. During digestion, a part of organic matter is converted to biogas which is either used for the production of hot tap water or electricity. The second part of sludge is drained and anaerobically stabilized sludge is formed which is used as bio-compost. The WWTP in Senec was built in 1964 , but it has been in permanent operation only since 2000. This WWTP serves for $68000 \mathrm{EQ}$. Samples of stabilized sludge were taken in December in 2015 .

\section{Monitoring of triclosan-resistant coliform bacteria and enterococci occurrence in stabilized sludge}

Coliform bacteria were detected on Chromocult Coliform agar plates (VWR Chemicals, USA), while Slanetz-Bartley agar (Biolife, Italy) was used in case 
of enterococci. Based on previous results obtained in the laboratory, concentrations of triclosan applied in the media were determined to be $100 \mu \mathrm{g}$ / $\mathrm{mL}, 200 \mu \mathrm{g} / \mathrm{mL}$ and $300 \mu \mathrm{g} / \mathrm{mL}$, thus significantly exceeding the MIC values of this biocide defined for the studied groups of bacteria. Coliforms were cultivated for $24 \mathrm{~h}$ at $37^{\circ} \mathrm{C}$, while cultivation conditions for Enterococcus spp. were $48 \mathrm{~h}$ and $40^{\circ} \mathrm{C}$. Colony forming units (CFU) of the observed bacteria were counted on parallel inoculated Petri dishes and the results were expressed as the number of CFU per gram (CFU/g) of stabilized sludge. Each experiment was repeated three times.

\section{Isolation and identification of triclosan-resistant coliform bacteria}

Coliform bacteria showing resistance to triclosan were isolated by the streak plate method on Mueller Hinton agar (Biolife, Italy) plates $\left(24 \mathrm{~h}, 37^{\circ} \mathrm{C}\right)$ and identified by a Matrix-Assisted Laser Desorption/ Ionization-Time of Flight (MALDI-TOF) mass spectrometer according to Lépesová et al. (2018).

\section{Determination of ATB susceptibility}

Susceptibility of triclosan-resistant coliform bacteria to ATBs including ampicillin (AMP), gentamicin (GEN), ciprofloxacin (CIP), chloramphenicol (CMP) and tetracycline (TET) was detected by the plate dilution drop method previously described in the study by Lépesová et al. (2018).

\section{Detection of biofilm formation}

Quantitative assessment of biofilm formation was detected by measuring the absorbance of biofilm eluate at $570 \mathrm{~nm}$ using a plate reader (BioTek, US) according to Beenken et al. (2003). Experiment was run in six parallels and it was repeated three times. The exact method for biofilm detection has been in details described by Lépesová et al. (2018).

\section{Results and Discussion}

\section{Occurrence of triclosan-resistant coliform bacteria and enterococci in stabilized sludge}

As a result of low acute toxicity and general safety for humans, triclosan has been used as an additive in various consumer products including toothpastes, soaps, deodorants or disinfectants for households and hospitals. However, frequent use of such products has resulted in an increased release of triclosan into wastewaters, stabilized sludge as well as recipients (Middleton and Salierno, 2013; Wang et al., 2018). Thus, occurrence of coliform bacteria and Enterococcus spp. resistant to triclosan in different samples of stabilized sludge was determined in the first part of the study. Since, in case of biocide agents such as triclosan, resistance limits are not given, concentrations nearly 1000 times higher than the MIC of triclosan defined for studied bacteria $(\mathrm{c} 1=100 \mu \mathrm{g} / \mathrm{mL}, \mathrm{c} 2=200 \mu \mathrm{g} / \mathrm{mL}$ and $\mathrm{c} 3=300 \mu \mathrm{g} /$ $\mathrm{mL}$ ) were chosen for the selection of resistant bacteria. The MIC value for triclosan ranges from $0.3 \mu \mathrm{g} / \mathrm{mL}$ to $0.64 \mu \mathrm{g} / \mathrm{mL}$ (Chuanchuen, 2003).

Figure 1 describes the ratio of coliform bacteria resistant to triclosan in the studied samples of stabilized sludge taken in December in 2015. The highest number of coliforms was recorded in the sludge sample from the WWTP in Petržalka (6.6 log CFU/g), while in the sample from the largest WWTP in Vrakuña, their number was slightly lower (6.0 $\log \mathrm{CFU} / \mathrm{g})$. In the stabilized sludge from the WWTP in Senec, the total number of coliform

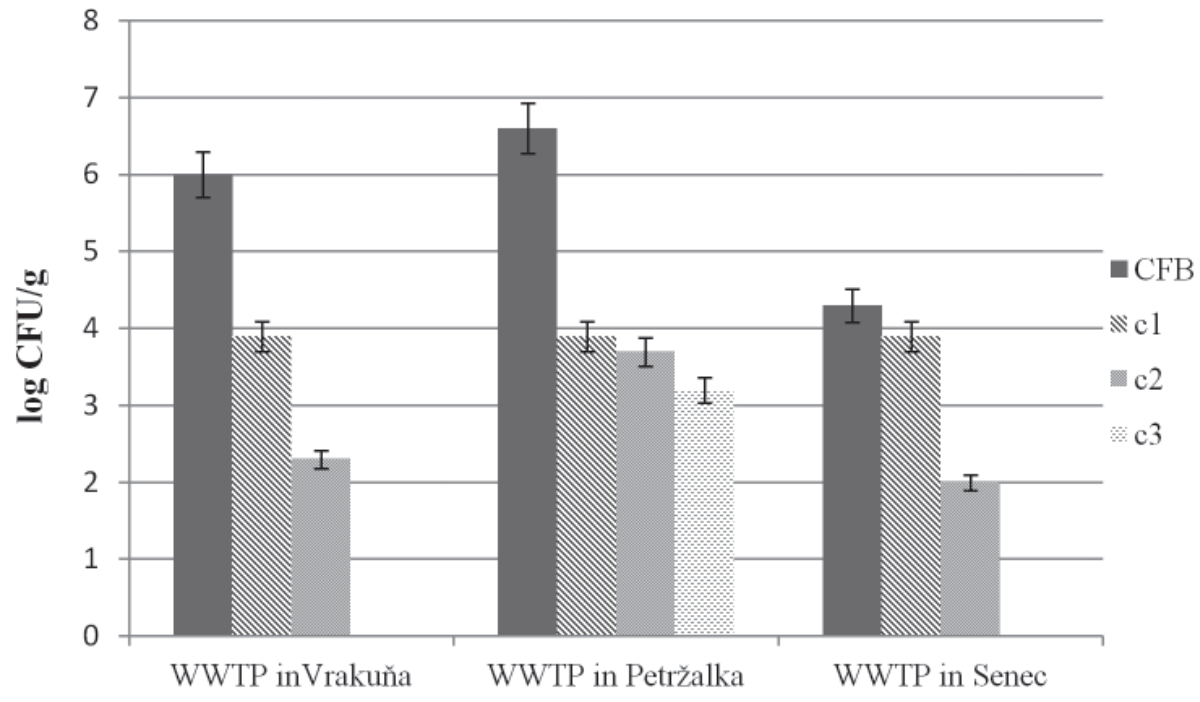

Fig. 2: Number of total and triclosan-resistant coliform bacteria in stabilized sludge. CFB - total coliform bacteria, c1 - triclosan $100 \mu \mathrm{g} / \mathrm{mL}, \mathrm{c} 2$ - triclosan $200 \mu \mathrm{g} / \mathrm{mL}$, c3 - triclosan $300 \mu \mathrm{g} / \mathrm{mL}$. 
bacteria was by 2.0 logarithmic orders lower (4.3 log GFU/g). While in case of the WWTP in Petržalka, about a half of the coliform strains showed resistance to all three applied concentrations of triclosan, in stabilized sludge from the WWTPs in Vrakuña and Senec, coliforms resistant to the highest concentration of triclosan $(\mathrm{c} 3=300 \mu \mathrm{g} / \mathrm{mL})$ were not detected. Although, the sample of stabilized sludge taken from the WWTP in Senec contained the lowest number of coliform bacteria, most of them (about $90 \%$ ) tolerated the lowest applied triclosan concentration (Fig. 2).

The presence of total enterococci was detected in all of three samples of stabilized sludge. The highest values were recorded again in the WWTP in Petržalka (5.2 log CFU/g) and the lowest ones in the WWTP in Senec (4.2 log CFU/g). However, no stabilized sludge sample contained triclosan-resistant enterococci. Other studies also confirmed the presence of triclosan resistant bacteria in waste and surface water, but none has studied triclosan resistance in sewage sludge nor in such high concentration of triclosan (Middleton and Salierno, 2013; Coetzee et al., 2017). As this biocide is lipophilic, its adsorption to sludge is much better compared to hydrophilic compounds. This also confirms our results that bacteria found in sewage sludge are more tolerant to very high triclosan concentrations.

\section{Identification of triclosan-resistant coliform isolates} For qualitative analysis of coliform isolates, MALDI-TOF mass spectrometry, recently introduced in many microbiological laboratories for routine identification of microorganisms (Hrabák et al., 2013), was employed. When identifying microorganisms by MALDI-TOF, an approach based on the generation of a unique spectrum ("fingerprint") of intact cells is used this is then compared to the reference spectrum (Santos et al., 2015).

Triclosan-resistant isolates were identified as Citrobacter freundii, Morganella morganii, Serratia fonticola and Serratia liquefaciens (Tab. 1). These types of bacteria can be found typically in soil, wastewaters, sewage, but also in food or in the intestinal tract of humans or animals (Wang, 2000; Liu et al., 2016). C. freundii can become an opportunistic pathogen that is mostly associated with urinary and respiratory infections (Santos et al., 2017). M. morganii were previously considered as pathogens of minor importance, however, they have been declared a significant cause of nosocomial infections in recent years (Liu et al., 2016). S. fonticola and S. liquefaciens are conditional human pathogens responsible for nosocomial, lower respiratory tract and urinary tract infections as well as for infections of skin or soft tissues (Aljorayid et al., 2016; Liu et al., 2017).

\section{ATB susceptibility profile of triclosan-resistant coliform isolates}

The increasing phenomenon of ATB and biocide resistance is a global problem that has been threatening public health for several decades. Increasing trend of bacterial resistance is due to the misuse of ATBs as well as the widespread use and misuse of biocidal agents not only in the hospital environment but also in the food industry and households. Most pharmaceuticals used in human infection treatment and prevention are only partially metabolized. Their metabolites are subsequently directed into the municipal wastewaters that flow through the sewage system to WWTPs. ATB residues resist the process of degradation in spite of the well-developed process of wastewater treatment (including biological degradation of drugs under anaerobic conditions in sludge towers) and consequently can accumulate in sludge (Birošová et al., 2014; Birošová and Mikulášová, 2014). Studies pointed out the problem of cross-resistance in triclosan-resistant isolates which are also ATB resistant (Birošová et al., 2009; Middleton and Salierno, 2013). Therefore, susceptibility of coliforms showing resistance to triclosan isolated from different samples of stabilized sludge to ATBs was tested. ATBs of different classes were applied in concentrations given by resistance limits reported for Enterobacteriaceae by the European Committee on Antimicrobial Susceptibility Testing for the EU (EUCAST) and by the Clinical Laboratory Standards Institute (CLSI) for the United States (Tab. 1).

Among $\beta$-lactam ATBs, AMP was chosen because of its frequent use in Slovakia (ECDC, 2017). However, according to Magiorakos et al. (2012) isolates identified as M. morganii and C. freundii are characterized by an intrinsic resistance to this ATB thanks to the chromosomally encoded $a m p C$ gene responsible for $\beta$-lactamase production. While $S$. fonticola is resistant to AMP in the CLSI concentration, isolates of $S$. liquefaciens showed resistance against this ATB according to the EUCAST (tab. 1). Both GEN and CIP can be present in wastewaters in higher levels due to their frequent use in the community as well as hospital sector (Lépesová et al., 2018). GEN resistance was observed only in M. morganii and C. freundii (CLSI) isolated from the stabilized sludge taken from the WWTP in Petržalka. Resistance to CIP showed only one isolate identified as $C$. freundii. Application of CMP is currently delimited, but bacterial strains exhibiting resistance to this ATB persist due to the possible mechanisms of cross-resistance (Birošová et al., 2014). Decreased susceptibility to CMP was observed in case of two coliform isolates (M. morganii and $C$. freundii) from the WWTP in Petržalka, which were able to grow 
Tab. 1. Identification and susceptibility testing of triclosan-resistant coliform isolates from stabilized sludge.

\begin{tabular}{|c|c|c|c|c|c|c|c|c|}
\hline $\begin{array}{l}\text { Stabilized } \\
\text { sludge }\end{array}$ & $\begin{array}{l}\text { Triclosan content } \\
(\propto \mathrm{g} / \mathrm{mL})\end{array}$ & Identification & AMP & GEN & CIP & CMP & TET & MDR \\
\hline \multirow{7}{*}{$\begin{array}{l}\text { WWTP } \\
\text { in Petržalka }\end{array}$} & 100 & M. morganii & INR & R2 & - & $\mathrm{R} 1$ & INR & - \\
\hline & 100 & C. freundii & INR & - & - & - & - & - \\
\hline & 300 & C. freundii & INR & - & - & - & - & - \\
\hline & 300 & C. freundii & INR & - & - & - & - & - \\
\hline & 200 & C. freundii & INR & - & $\mathrm{R} 2$ & $\mathrm{R} 1$ & - & - \\
\hline & 300 & C. freundii & INR & - & - & - & - & - \\
\hline & 200 & C. freundii & INR & $\mathrm{R} 2$ & - & - & - & - \\
\hline WWTP & 200 & S. fonticola & R2 & - & - & - & - & - \\
\hline in Senec & 200 & S. liquefaciens & $\mathrm{R} 1$ & - & - & - & - & - \\
\hline $\begin{array}{l}\text { WWTP } \\
\text { in Vrakuňa }\end{array}$ & 200 & S. liquefaciens & $\mathrm{R} 1$ & - & - & - & - & - \\
\hline
\end{tabular}

AMP - ampicillin, GEN - gentamicin, GIP - ciprofloxacin, CMP - chloramphenicol, TET - tetracycline.

MDR - multidrug-resistant, INR - intrinsic resistance.

R1 - resistance according to the EUCAST, R2 - resistance according to the CLSI.

only at the concentration defined by the EUCAST (Tab. 1).

Although TET is not used as much as AMP or CIP, its selection pressure persists particularly because of the use of oxytetracycline for veterinary praxis (Birošová et al., 2014). From Table 1 it is evident that M. morganii can be characterized by intrinsic resistance to TET (Magiorakos et al., 2012). Except for this isolate, resistance to TET was not recorded in any triclosan-resistant isolates.

Based on the number of ATB classes against which coliform isolates showed resistance, their multidrug-resistance (MDR) character was recorded. According to Magiorakos et al. (2012), only microorganisms resistant to antimicrobial substances included in three or more ATB classes can be considered as MDR. This condition was not met in case of the tested coliform isolates (Tab. 1).

\section{Biofilm forming ability of triclosan-resistant coliform isolates}

Biofilm is defined as microbial population adhering to biotic and abiotic surfaces which is enclosed in an extracellular matrix of a polymeric substance (exopolysaccharides) (Donlan, 2002). Biofilms are a source of severe infections and are difficult to remove and problematic to control. Benefit of biofilm community is the protection against ATBs, disinfectants and environmental dynamics (Garrett et al., 2008). Biofilm formation can also be beneficial for the human population; it is used in biological wastewater treatment in WWTPs and in biotechnological processes, in particular for the removal of pollutants such as metals, radionu- clides, oil or nitrogen compounds (Sehar and Naz, 2016). On the other hand, high bacterial density and diversity are found in biofilms from wastewater systems; especially from activated sludge of sewage treatment plants which support horizontal gene transfer in the bacteria population (Lépesová et al., 2018).

Since bacteria in biofilms can be much more resistant to ATBs as well as to other environmental stress factors, the ability of triclosan-resistant coliforms isolated from stabilized sludge to form biofilm was determined (Fig. 3).

Based on the absorbance values, the tested isolates were classified as weak, medium, strong and very strong producers of bacterial biofilm according to the scale developed by Taniguchi et al. (2009). All isolates of $C$. freundii as well as those of $M$. morganii and $S$. liquefaciens were strong producers of bacterial biofilm. Second isolate of S. liquefaciens from the WWTP in Senec and S. fonticola from the WWTP in Vrakuňa were able to form biofilms with medium intensity (Fig. 3).

The annual production of stabilized sludge in Slovakia is about 58000 tons, most of which is transferred to the composting plant where it is mixed with compost. In 2012, 36832 tons of stabilized sludge were processed into compost and up to 1139 tons were applied directly to soil (Birošová et al., 2014). Many studies highlight the risk of sludge application because of the content of ATBs and their metabolites, biocides or heavy metals at subinhibitory concentrations, which play a role in stimulating both the emergence of bacterial resistance by mutations as well as the horizontal 


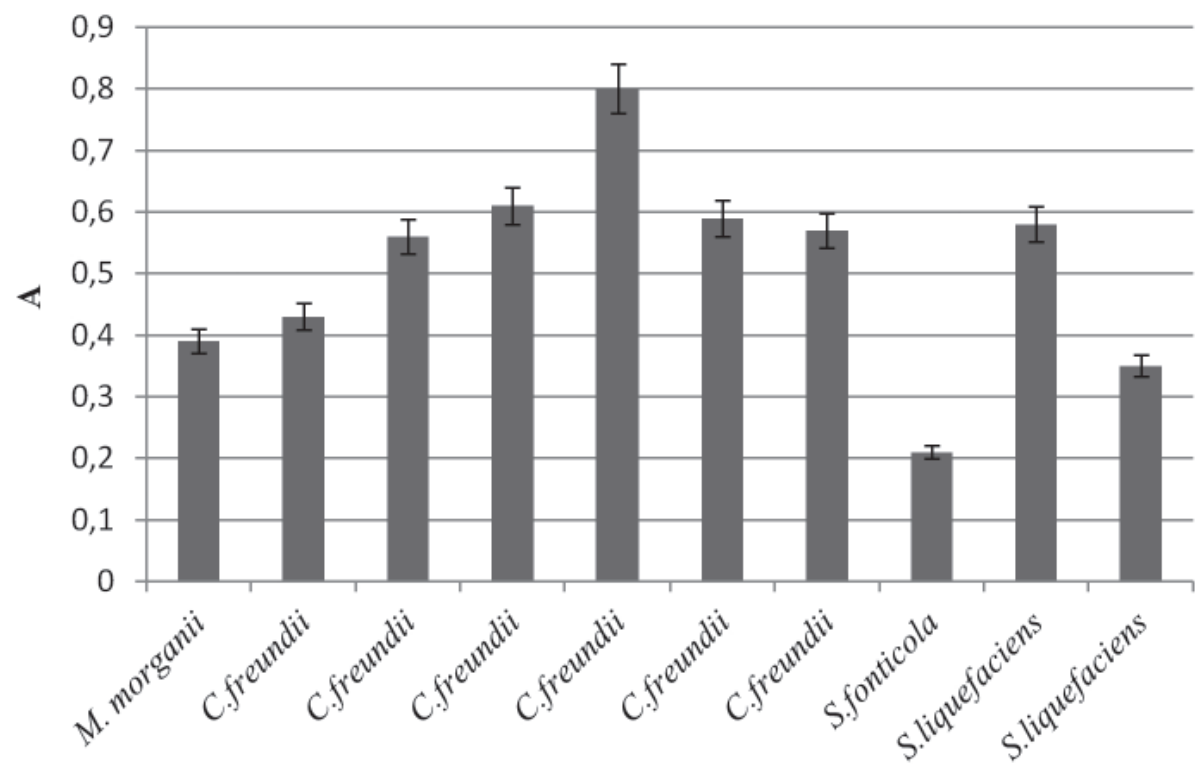

Fig. 3. Biofilm forming ability of triclosan-resistant coliform bacteria. A - Absorbance.

gene transfer rate (Baquero a kol., 2008; Birošová et al., 2014; Makowska a kol., 2016). In addition to the spread of chemical agents from the stabilized sludge into the environment, it was also shown that sludge contains an abundant number of coliform bacteria able to spread the resistance phenomenon (Reinthaler et al, 2010; Birošová et al., 2014).

\section{Conclusions}

Currently, there is convincing evidence that common mechanisms responsible for resistance to biocides and ATBs are present in bacteria and can be acquired by mobile genetic elements. Our data show that coliform bacteria present in sewage sludge are able to resist very high concentrations of triclosan. Approximately half of coliform isolates were also ATB resistant and the majority of them are strong biofilm producers.

The high prevalence of triclosan-resistant coliform bacteria in stabilized sludge represents a potential risk of direct application of sludge to soil due to the development and spread of bacterial resistance in the ecosystem.

\section{Acknowledgements}

This work was supported by the Slovak Research and Development Agency (grant no. APVV-16-0171), the Scientific Grant Agency VEGA (grant no. VEGA 1/0096/17) and by a project for building of infrastructure for modern research of civilization diseases (ITMS 26230120006).

\section{References}

Aiello AE, Larson EL, Levy SB (2007) Clinical Infectious Diseases 1, Oxford Journals 45: S137-S147.
Aljorayid A, Viau R, Castellino L, Jump RLP (2016) Idcases 5: 6-8.

Baková A (2016) Bachelor Thesis, p. 1-56, Bratislava (In Slovak).

Baquero F, Martínez JL, Cantón R (2008) Current Opinion In Biotechnology 19: 260-265.

Beenken KE, Blevins JS, Smeltzer MS (2003) Infection And Immunity 7: 4206-4211.

Birošová L, Mikulášová M (2009) Journal Of Medical Microbiology 58: 436-441.

Birošová L, Mikulášová M (2014) Biomedical Papers 158 (2): 315-320.

Birošová L, Mackulak T, Bodík I, Ryba J, Škubák J, Grabic R (2014) Science Of The Total Environment 490: 440-444.

Butler E, Whelan MJ, Sakrabani R, Egmond R (2012) Environmental Pollution 167: 107-109.

Carey DE, Mcnamara PJ (2015) Frontiers In Microbiology 5: $1-11$.

Chen X, Nielsen JL, Furgal K, Liu Y, Lolas IB, Bester K (2011) Chemosphere 84: 452-456.

Chuanchuen R (2003) American Journal Of Infection Control 31(2): 124-127.

Coetzee I, Bezuidenhout CC, Bezuidenhout JJ (2017) Water Science \& Technology 76(6): 1500-1509.

Donlan RM (2002) Emerging Infectious Diseases 8(9): 881-890.

European Centre for Disease Prevention and Control (2017) Stockholm, Sweden: ECDC; 2017, ISBN 978-929498-099-1, p. 1-11.

European Comission, Scientific Committee On Consumer Safety, EC (2010) European Union, ISBN 978-92-79-12484-6, p. 1-56.

Fraise AP (2002) Journal Of Antimicrobial Chemotherapy 1, Oxford Journals 49: 11-12.

Garrett TR, Bhakoo M, Zhang Z (2008) Progress In Natural Science 18 (9): 1049-1056.

Gatidou G, Thomaidis NS, Stasinakis AS, Lekkas TD (2007) Journal Of Chromatography A 1138: 32-41.

Hrabák J, Chudáčková E, Walková R (2013) Clinical Microbiology Reviews 26: 103-114. 
Kalkanci A, Elli M, Adil Fouad A, Yesilyurt E, Jabban Khalil I (2015) Journal De Mycologie Médicale 25: 280-286.

Kim Y, Murugesan K, Schmidt S, Bokare V, Jeon JR, Kim EJ, Chang YS (2011) Bioresource Technology 102: 2206-2212.

Lavilla Lerma L, Benomar N, Casado Muñoz Mdel C, Gálvez A, Abriouel H (2015) Food Microbiology 51: 33-44.

Lee DG, Chu KH (2013) Chemosphere 93: 1904-1911.

Lépesová K, Kraková L, Pangallo D, Medvedová A, Olejníková P, Mackulak T, Tichý J, Grabic R, Birošová L (2018) Journal Of Global Antimicrobial Resistance 14: $145-151$.

Liu H, Zhu J, Hu Q, Rao X (2016) International Journal Of Infectious Diseases 50: 10-17.

Liu J, Yu S, Han B, Chen J (2017) Food Control 78: 196-202.

Mackulak T, Birošová L, Grabic R, Škubák J, Bodík I (2015a) Environmental Science And Pollution Research 22: 14000-14006.

Mackulak T, Nagyová K, Faberová M, Grabic R, Koba O, Gál M, Birošová L (2015b) Environmental Toxicology And Pharmacology 40: 492-497.

Magiorakos AP, Srinivasan A, Carey RB, Carmeli Y, Falagas ME, Giske CG, Harbarth S, Hindler HF, Kahlmeter G, Olsson-Liljequist B, Paterson DL, Rice LB, Stelling J, Struelens MJ, Vatopoulos A, Weber JT, Monnet DL (2012) Clinical Microbiology And Infection 18: 268-281.

Makowska N, Koczura R, Mokracka J (2016) Chemosphere 144: 1665-1673.
Middleton JH, Salierno JD (2013) Ecotoxicology and Environmental Safety 88 : 79-88.

Nuñez L, Moretton J (2007) Brazilian Journal Of Microbiology 38: 644-648.

Pintado-Herrera MG, González-Mazo E, Lara-Martín PA (2014) Chemosphere 95: 478-485.

Reinthaler FF, Feierl G, Galler H, Haas D, Leitner E, Mascher F, Melkes A, Posch J, Winter I, Zarfel G, Marth E (2010) Water Research 44: 1981-1985.

Rule KL, Ebett VR, Vikesland PJ (2005). Journal Environmental Science and Technology 39(9): 3176-85.

Santos C, Ramalheira E, Da Silva G, Mendo S (2017) Journal of Global Antimicrobial Resistance 8: 18-22.

Santos T, Capelo JL, Santos HM, Oliveira I, Marinho C, Gonçalves A, Araújo JE, Poeta P, Igrejas G (2015) Journal of Proteomics 127: 321-331.

Sheridan À, Lenahan M, Duffy G, Fanning S, Burgess CM (2012) Food Control 26: 98-106.

Sehar S, Naz I (2016) Intech Open, Chapter 7: 121-144.

Singer H, Müller S, Tixier C, Pillonel L (2002) Environmental Science \& Technology 36: 4998-5004.

Taniguchi L, De Fátima Faria B, Rosa RT, De Paula E Carvalho A, Gursky LC, Elifio-Esposito SL, Parahitiyawa N, Samaranayake LP, Rosa EA (2009) Journal of Microbiological Methods 78: 171-174.

Wang JT, Chang SC, Chen YC, Luh KT (2000) Journal Of Microbiology, Immunology And Infection 33(4): 258-62.

Wang S, Poon K, Cai Z (2018) Journal Of Hazardous Materials 342: 643-650. 